\title{
The Effect of Self-Regulated and Disciplined Learning on Students' Achievements
}

\author{
$1^{\text {st }}$ Ahmad Susanto \\ Faculty of Education Science \\ Universitas Muhammadiyah Jakarta \\ Jakarta, Indonesia \\ ahm_susanto@umj.ac.id
}

\author{
$2^{\text {nd }}$ Farihen \\ Faculty of Education Science \\ Universitas Muhammadiyah Jakarta \\ Jakarta, Indonesia
}

\author{
$3^{\text {rd }}$ Iswan \\ Faculty of Education Science \\ Universitas Muhammadiyah Jakarta \\ Jakarta, Indonesia
}

\begin{abstract}
The background of this study is the still low self-regulated learning and learning discipline for students. The purpose of this study was to examine the effect of selfregulated learning and learning discipline on student achievement, especially on social science subjects. The research method used is descriptive survey method. Data retrieval is done by questionnaires. Data analysis used a descriptive statistical method to find partial and multiple correlation coefficient with ttest. The result showed: 1) there was a significant effect of self-regulated and discipline learning together on learning achievement in social sciences. This is evidenced by the value of $\mathrm{sig}=$ $0,001<0.05$ and Fcount $=37.61$. Whereas self-regulated and discipline learning to the learning achievement of social sciences. 2) There is a significant effect of self-regulated learning on learning achievement in social sciences. This is evidenced by the acquisition tcount=3.617. 3) There is a significant effect of discipline learning on learning achievement in social sciences. This is evidenced by the sig= $0.001<0.05$ and tcount of 3.617.
\end{abstract}

Keywords - self-regulated, discipline, Learning Achievement of Social Sciences.

\section{INTRODUCTION}

In fact, so far there are still many students who do not understand the importance of self-regulated learning, about how to develop an attitude of independence in themselves, and about the advantages that can be obtained if students can develop an attitude of independence in their lives. If students do not have self-regulated learning they will always depend on what is given by the teacher, without any effort to confirm and develop the information provided by the teacher[1]. This will be very detrimental for these students, especially if this attitude will be carried over until they study in tertiary institutions which are more demanded to develop and explore information independently [2]. In the management of learning, discipline is an important issue[3]. Without an awareness of the necessity to implement predetermined rules, learning is not possible to reach the maximum target. Independence is one of the most important aspects of personality for an individual. Individuals who have high independence are relatively able to face all problems because independent individuals are not dependent on others, always trying to face and solve the problems they face.

\section{LITERATURE REVIEW}

\section{A. Discipline Learning}

A student needs to have a disciplined attitude by doing exercises that strengthen himself to always be accustomed to obey and enhance self-control. A discipline that arises from his own awareness will be more stimulating and long-lasting compared to the attitude of a discipline that arises because of the supervision of others.

Discipline can grow and be fostered through training, education or inculcation of habits that must begin in the family environment, starting in childhood and continue to grow so that discipline becomes stronger [3]. As stated by Kadambari that with discipline that arises because of selfawareness, students succeed in their learning, without good discipline the atmosphere of the school and also the class becomes less conducive to learning activities in a positive manner discipline provides support for a calm and calm environment orderly for the learning process, discipline is a way for students to succeed in learning and later when working because of the awareness of the importance of norms, rules, obedience and obedience is one's success[1].

According to Mota \& Scott the attitude of a person's behavior is not formed in an instant. Coaching is needed, continuous forging from an early age. Through human forging will be strong. Through mental and moral forging someone will be tested, through forging also makes someone able to overcome problems with determination and perseverance[4].

Through forging they also get added value. Discipline will be realized through coaching from an early age, from a young age, starting from the family environment through education that is embedded from a young age which is increasingly integrated with him as he ages. So 
that in this case in education, especially in schools, discipline must be able to be applied to students, of course, with the process and method of application and ongoing coaching that makes students have discipline in the world of schools that apply in the world of education[5].

In addition to independence, student success in learning is also influenced by other factors that are no less important, namely student learning discipline. Discipline is a condition that is created and formed through the process of a series of behaviors that demonstrate the value of obedience, obedience, loyalty, order, and order.[1] Learning discipline shows the values of obedience and regularity in learning based on moral values that apply in the learning environment [6]. If students study regularly or study with high discipline, it is possible to achieve satisfying learning achievements as expected. While the problem is that the discipline of student learning in schools tends to be low [7].

\section{B. Self-Regulated Learning}

Independence is the ability to manage everything that is owned, know how to manage time, walk, and think independently accompanied by the ability to take risks and solve problems. An independent individual does not need detailed and continuous guidance on how to reach the final product, but he can rely on himself. (Parker, 2005: 226). Independence in learning is how he achieves something and can succeed in learning independently, without having to be watched and forced by others.

According to Erikson in Monks (2002: 272) relating to learning independence is an attitude to break away from the guidance and supervision of others, especially parents, with a view to find oneself by the process of searching for ego identity, namely the development of steady directions for independent learning.

\section{METHOD}

The research method used is a survey with correlational techniques. This survey research method as an observation to get clear information about a particular problem in a study.

This research is carried out for an action that is descriptive in nature, namely describing things that contain facts, clarification and measurement to be measured is a fact whose function is to formulate and describe what happened.

The variable of this study consisted of dependent variables, namely social studies learning achievement $(\mathrm{Y})$ and two independent variables, namely self-regulated learning $\left(\mathrm{X}_{1}\right)$ and learning discipline $\left(\mathrm{X}_{2}\right)$.

The technique for obtaining data from respondents uses a questionnaire (questionnaire). Data analysis with the descriptive statistical method, multiple person correlation coefficient, coefficient of determination and regression analysis. Statistical tests using t test and test $f$.

The chart of the correlation method between the three variants is as follows:

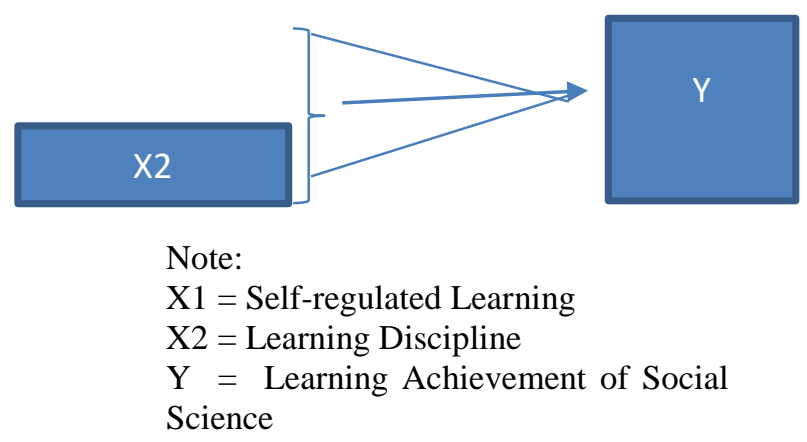

III. RESULT AND DISCUSSION

\section{A. Data Description}

Based on the results of the study what has been done about the effect of self-regulated learning and learning discipline on the achievement of learning social science obtained the following results.

1) Data of Achievement learning of social learning (Y)

Social Sciences learning achievement data were obtained from the Semester Final Examination scores of 56 students who became the study sample. The value obtained is the lowest value 58 , the highest 95 , the average is 76.52 , the median is 75 , the mode is 75 , and the standard deviation is 9,352 .

TABEL 1. RESEARCH DATA DESCRIPTION OF SOCIAL SCIENCE ACHIEVEMENT

\begin{tabular}{|l|l|r|}
\hline \multicolumn{2}{|c|}{ Statistics } \\
\hline \multicolumn{2}{|c|}{ Achievement of Social Science Learning } \\
\hline \multirow{2}{*}{$\mathrm{N}$} & Valid & 56 \\
\cline { 2 - 3 } & Missing & 0 \\
\hline Mean & 76.52 \\
\hline Median & 75.00 \\
\hline Mode & 75 \\
\hline Std Deviation & 9.352 \\
\hline Minimum & 58 \\
\hline Maximum & 95 \\
\hline
\end{tabular}

When viewed from the results of the calculations above, it can be said that the learning achievement of students in Social Sciences is quite good. This is indicated by the acquisition of an average value of 76.52.

\section{2) Data of Self-Regulated Learning (XI)}

Self-regulated learning data obtained from questionnaires answered by 56 students produced the lowest score of 79, highest score of 117 , average score of 99.25 , median 99 , mode of 99 , and standard deviation of 9,500.

TABLE 2. RESEARCH DATA DESCRIPTION OF SELFREGULATED LEARNING

\begin{tabular}{|l|l|r|}
\hline \multicolumn{2}{|c|}{ Statistics } \\
\hline \multicolumn{2}{|c|}{ Self-regulated Learning } \\
\hline \multirow{2}{*}{$\mathrm{N}$} & Valid & 56 \\
\cline { 2 - 3 } & Missing & 0 \\
\hline \multicolumn{2}{|l|}{ Mean } & 99.25 \\
\hline Median & 99.00 \\
\hline Mode & 99 \\
\hline \multicolumn{2}{|l|}{ Std Deviation } & 9.590 \\
\hline
\end{tabular}




\begin{tabular}{|l|r|}
\hline Minimum & 79 \\
\hline Maximum & 117 \\
\hline
\end{tabular}

From the results of the calculation above, it can be said that the students' self-regulated learning is good. This is indicated by the acquisition of a mean score of 99.25 higher than the median value.

3) Data of Learning Discipline (X2)

Learning discipline data obtained from questionnaires answered by 56 respondents produced the lowest score of 87 , highest score of 122 , an average score of 106.61 , median 107, mode 107 and standard deviation of 9. 513. TABLE 3. RESEARCH DATA DESCRIPTION OF LEARNING DISCIPLINE

\begin{tabular}{|c|c|c|}
\hline \multicolumn{3}{|c|}{ Statistics } \\
\hline \multicolumn{3}{|c|}{ Learning Discipline } \\
\hline \multirow[b]{2}{*}{$\mathrm{N}$} & Valid & 56 \\
\hline & Missing & 0 \\
\hline \multicolumn{2}{|c|}{ Mean } & 106.61 \\
\hline \multicolumn{2}{|c|}{ Median } & 107.00 \\
\hline \multicolumn{2}{|c|}{ Mode } & 107 \\
\hline \multicolumn{2}{|c|}{ Std Deviation } & 9.513 \\
\hline \multicolumn{2}{|c|}{ Minimum } & 87 \\
\hline \multicolumn{2}{|c|}{ Maximum } & 122 \\
\hline
\end{tabular}

From the results of the above calculations, it can be said that student learning discipline is quite good. This is indicated by the acquisition of a mean score of 106.61 approaching the median score.

\section{B. Hypothesis testing}

1) The Effect of Self-regulated learning(X1) and Learning discipline (X2) together towards Social Sciences Learning Achievement $(Y)$

Hypothesis testing: $\mathrm{H} 0: \beta y 1=\beta y 2=0 \mathrm{H} 1: \beta y 1 \neq 0$; $\beta \mathrm{y} 2 \neq 0$. Means; H0: There is no effect of self-regulated learning and learning discipline to learn together towards learning achievement in Social Sciences. H1: There are influences of self-concept and motivation to learn together towards the achievement of learning social science.

TABLE 4. RESULTS OF CALCULATION OF SIGNIFICANCE TESTING OF VARIABLE COEFFICIENT OF X1 AND X2 ON Y.

\begin{tabular}{|c|c|c|c|c|c|c|}
\hline & & & $\overline{\mathrm{OV}}$ & & & \\
\hline & & Sum of & $\mathrm{df}$ & Means & $\mathrm{F}$ & Sig \\
\hline & Regression & 1706.019 & 2 & 852.506 & 14.552 & .000 \\
\hline 1 & Residual & 3104.964 & 53 & 58.564 & & \\
\hline & Total & 4809.982 & 56 & & & \\
\hline a. & $\begin{array}{l}\text { Depe } \\
\text { evement }\end{array}$ & ent Variable: $\mathrm{S}$ & cial & ience Learr & & \\
\hline
\end{tabular}

From table 4 above it can be stated that there is a significant effect of self-regulated learning and learning discipline to learn together on the achievement of learning social science. This is evidenced by the acquisition of the Sig. $0,000<0.005$ and $\mathrm{Fo}=14,552$.

2) The Effect of Self-regulated learning (X1) towards Social Science Learning Achievement $(Y)$

Hypothesis testing: $\mathrm{H} 0: \beta y 1=0 \mathrm{H} 1: \beta \mathrm{y} 1 \neq 0$. Means; H0: There is no influence of self-regulated towards learning discipline in Social Sciences. H1: There are influences of self-concept towards the achievement of learning social science.

TABLE 5: RESULT OF VARIABLE X1 AND X2 DOUBLE REGRESSION EQUATIONS TO Y

\begin{tabular}{|c|c|c|c|c|c|c|}
\hline \multicolumn{7}{|c|}{ Coefficients } \\
\hline \multirow{2}{*}{\multicolumn{2}{|c|}{ Model }} & \multicolumn{2}{|c|}{$\begin{array}{l}\text { Unstandardized } \\
\text { Coefficients }\end{array}$} & \multirow{2}{*}{$\begin{array}{l}\text { Standardized } \\
\text { Coefficients } \\
\text { Beta }\end{array}$} & \multirow[t]{2}{*}{$\mathrm{t}$} & \multirow[t]{2}{*}{ Sig. } \\
\hline & & B & $\begin{array}{l}\text { Std. } \\
\text { Error }\end{array}$ & & & \\
\hline \multirow{3}{*}{1} & (Constant) & 8.332 & 12.799 & & .651 & .518 \\
\hline & $\begin{array}{l}\text { Self- } \\
\text { regulated } \\
\text { learning }\end{array}$ & .370 & .127 & .380 & 2.823 & .005 \\
\hline & $\begin{array}{l}\text { Learning } \\
\text { Discipline }\end{array}$ & .295 & .128 & .300 & 2.307 & .025 \\
\hline
\end{tabular}

Based on table 5 above, it can be stated that there is a significant effect of self-regulated learning on learning achievement in social science. This is evidenced by the acquisition of the Sig. $0.005<0.05$ and $t$ count $=2.923$.

3) The Effect of Learning Discipline (X2) towards Social Science Learning Achievement $(Y)$

Hypothesis testing: $\mathrm{H} 0: \beta y 1=0 \mathrm{H} 1: \beta y 1 \neq 0$. Means; H0: There is no effect of learning discipline towards learning achievement in Social Sciences. H1: There are influences of learning discipline towards the achievement of learning social science.

Based on table 5 above, it can be stated that there is a significant effect of learning discipline on the achievement of learning social science. This is evidenced by the acquisition of $t$ count $=2,307$ and Sig. $0.025<0.05$.

\section{CONCLUSIONS}

Based on the findings, the writers conclude that in general, the implementation of picture mnemonics in teaching English vocabulary to the eighth secondary students with intellectual disability at State Special School Purwosari Kudus, Central Java Province, Indonesia was in very good criteria with 3.69 score. Related to the teaching presentation aspect, the principles of picture mnemonics implementation had been successfully fulfilled by the teacher, such as presentation, association and retrieval. It was also found that there was improvement on students' vocabulary retention. Moreover, dealing with students' behavior aspect, during the implementation of the picture mnemonics the students were active, involved and enjoyed the teaching learning process. Considering the benefits of using picture mnemonics, it is suggested to use these picture mnemonics especially when teaching students with disability.

\section{REFERENCES}

[1] [1] Zimmerson, BJ. (Ed), Schunk, DH. (Ed), Review of SelfRegulated Learning and Academic Achievement: Theory, Research, and Practice., vol. 36, no. 11. 1991.

[2] Gili, Marbach, Laura, C. Egan and Katerina, V Thompson (1989), A Discipline- Based Teaching and Learning. .

[3] Kadambari, D, Kumar, S, Zayapragassarazass Z, and P. SC, (2018) Improving Discipline-Based Undergraduate Medical Curriculum.

[4] R. Mota, D. Scott, R. Mota, and D. Scott, "Independent Learning: 
A Strategy for Innovation,” Educ. Innov. Indep. Learn., vol. 6, pp. 73-95, 2014.

[5] M. K. Dibenedetto, (2018) Connecting Self-regulated Learning Performance with Instruction Across High School Content Areas.

[6] Hargis (2007), The Self Regulated Learner Advantage: Learning Science. Tersedia: http://wolfwe.unr.edu/homepagecrow/ejse/hargis.html. Diunduh 28 Nopember 2019.

[7] Kerlin (2009), Cognitive Engagement Style, Self-Regulated Learning and Cooperative Learning. http://kerlins.netbobbi/research/myresearch/srl.htm. Diunduh: 23/11/2019.

[8] Nugroho (2009), Self-Regulated Learning Anak Berbakat.
Tersedia: http://www. ditplb.or.id/2006/index.php?menu=profile\&pro=194.

[9] Wilson (2007), Self Regulated Learner and Distance Education Theory,

http://www.usask.ca/education/coursework/802papaers/wilson/wil son. html. Diunduh 28/11/2019.

[10] Wolters (2007), Assesing Academic Self-Regulated Learning, http://72.14.235.104/

search?q=cache:6vm54CNHnoJ.www.children.prg/files/woltersPr intichKarabenickPaper. Diunduh 23/1/2019. 